\title{
COMPLEXITY AND INTERACTION: COMPARING THE DEVELOPMENT OF L1 AND L2
}

\author{
Minna Suni and Lea Nieminen \\ University of Jyväskylä
}

\begin{abstract}
In research into first and second language development, the focus has mainly been either on the formal features of learner language alone (both L1 and L2) or on the interaction between learners and their caretakers (L1) or native speaker peers (L2). These research traditions have been kept apart even though it has been widely acknowledged that both first and second languages are appropriated essentially in social interaction. This paper aims to strengthen the connection between social and formal approaches by combining interactional views with those focusing on the structural complexity of learner language. Some excerpts from L1 and L2 interaction data (in the Finnish language) are discussed. It is suggested that segmentation of linguistic material occurs in everyday situations and serves as a link between interaction and the growth of structural complexity in learner language. To situate this argument into a broader theoretical framework, various socially oriented research paradigms are briefly discussed.
\end{abstract}

Keywords: first language, second language, interaction, structural complexity, segmentation, Finnish language

\section{Introduction}

Complexity and interaction have usually been kept apart in both first language (L1) and second language (L2) research. In previous research work the present writers have approached these themes from rather different angles, but ended up with concordant considerations: Nieminen (2007) has analysed the growth of morpho-syntactic complexity in L1 Finnish, and Suni (2008) the interactional segmentation processes in an L2 Finnish context. In this paper, we aim to combine these perspectives by discussing how structural complexity and shared processing of linguistic elements are related in the development of L1 and L2. We look 
for points of contact in results from L1 and L2 studies with special reference to the acquisition of Finnish morphosyntax. The main conclusion of our findings will be that the growth of complexity is not based on individual effort but on co-operation with others, and segmentation acts as a link between complexity and interaction. In our discussion some socially oriented research paradigms are briefly discussed to situate the findings in a broader theoretical and analytical framework and to pave the way for further analyses.

Before going into very much detail, some basic features of the Finnish language need to be explained, however, to clarify why the developing morphosyntactic complexity of learner Finnish is worth investigating. First of all, the Finnish morphosyntactic system can be described as a rich and varied combination of morphological, morphophonological and syntactic phenomena which are tightly intertwined in utterances. This provides a fruitful setting for analysing how morphosyntax is dealt with in the interactional L1 and L2 context.

There are approximately 40 inflectional suffixes in Finnish, including infinitives and participles (Karlsson 1983: 231). It has been estimated that, in principle, each noun has 2,200 and each verb 12,000 different inflectional forms (ibid. 356-57), although not all of them are in daily use. Apart from the considerable number of suffixes, morphophonological variation is a very common phenomenon in Finnish and it affects both stems and suffixes. The basically agglutinative morphology of Finnish is constantly supplemented with fusional features (e.g. Karlsson 1998: 92-93).

The close relationship between morphology and syntax manifests itself in several ways. The morphological marking of basic sentence constituents such as object gives more freedom over word order (Karlsson 1998: 168). Another property of Finnish which combines syntactic and morphological systems is agreement. Purely morphological agreement, which indicates that the modifier and the head of a noun phrase agree in number and case, shows which words are related (e.g. iso + ssa punaise + ssa talo+ssa, big+INESSIVE red+INESSIVE house+INESSIVE 'in a big red house'), but also multiplies the frequency of suffixes and therefore makes them more salient. Likewise, semantic agreement, that is, the personal agreement between subject and verb predicate in a sentence (e.g. minä istu+n, I sit+SG1 'I sit'; 
sinä istu $+t$, you sit+SG2 'you sit'), gives redundant information, since the subject is referred to by both the subject word itself and the personal suffix in the verb predicate.

At first glance, the Finnish morphosyntactic system may appear to be challenging. However, many of the Finnish morphological elements are phonologically salient as well as frequently used because of agreement rules, and this makes them easier to perceive. A rich morphological system also gives plenty of opportunity for analogous use of language. Since there is a large variety of inflected words available in the linguistic environment, a learner is surrounded by a diverse arsenal of patterns, which helps him/her to use analogous word forms without actually inflecting anything. This raises the question of the actual units that learners are processing at different stages of the learning process: do the intricately interrelated morphology and syntax set the scene for construction based learning, or is the learner forced to segment language chunks earlier than with more analytical languages?

Focusing on Finnish obviously allows analyses that are not possible in less inflective languages. The plausibility of some learning-oriented models has already been tested by analysing learner Finnish (e.g. Martin 2004). Similarly, the interpretation of results from measures like Mean Length of Utterance (MLU; Brown 1973) and Index of Productive Syntax (IPSyn; Scarborough 1990) has to be seriously reconsidered when these measures of morphosyntactic complexity are applied to a language in which the relationship between a rich morphological system and a large variety of syntactic structures is as intricate as it is in Finnish (see Nieminen 2007).

\section{Social and formal approaches to first and second language development}

It is commonly acknowledged that language is not inherent but is socially mediated from one generation to another, but what socially driven language learning means has been interpreted somewhat differently at different times. Language development is facilitated by awareness of the intentionality of other people, and joint attention to surrounding linguistic material. Support and help from others plays an important role in first language de- 
velopment, and in much of its use, too (Vygotsky 1978). Second language parallels first language here: it, too, is primarily learnt through interaction with members of the surrounding community, and feedback and timely support are usually seen as being among the key factors facilitating the process (e.g. Ervin-Tripp 1994, Lantolf and Thorne 2006). Noticing new linguistic features in input has been taken as a prerequisite for learning since the 1980s (e.g. Krashen 1982, Long 1985), but more recently participation in language interaction has been seen as an even more significant issue. It has been argued that the same situation or action serves as a different learning environment for different individuals; that part of what is available which applies to any particular individual's needs will turn into "affordance". The concept of affordance refers to possibilities for action that are relevant to one's own individual learning process (van Lier 2000).

In spite of the social origin and context of both first and second language learning, research has largely focused on selfinitiated speech production and outcomes of the learning process, as if speech were produced in a vacuum (Laakso 2008: 150, Suni 2008: 34). Even if interactional data have been used, only the contribution of one individual, the learner, has usually been analysed at all closely. To limit the analysis to a purely individual linguistic repertoire, the further selection of data has been based on such criteria as non-occurrence of imitation or other repetitive elements which imply that other speakers' turns have been utilized in speech production (e.g. Brown 1973, Pienemann 1998 and Scarborough 1991), but in such studies the social and interactional elements have quite deliberately been filtered out from the database, and only the monologically produced forms have been subjected to closer analysis.

At the other end of the continuum are studies focusing on sequential patterns of interaction while ignoring the learning of linguistic forms and meanings. Interaction between child and caretaker or native and non-native speaker has been analysed since the 1970s with a focus on linguistic registers such as motherese, and foreigner talk (Ervin-Tripp 1974, Ferguson 1975). Also the various possible functions of repetition in first language learning have been analysed rather early, but the processing of linguistic forms has not been mentioned when the functions of repetition have been identified (e.g. Keenan 1974, Snow 1979). In conversation analytic (CA) studies, turn taking and repair or- 
ganization, and the general sequential order of talk have been the target of detailed analysis, but their role in language learning has only recently started to become a research target as such (CA for SLA, see e.g. Kurhila 2006, Laakso 2008, Lilja 2010). For a long time learning was rejected as a research topic within CA.

In second language research, especially Long (1983 and 1996) and Gass (1997) have emphasized the interface between social and linguistic aspects. Their inspiring approaches have not offered adequate methods for analysing both aspects simultaneously, however, and much more attention has actually been paid to the learner side than to that of the other interlocutor(s) or the communicative setting as a whole. Studies focusing on negotiated interaction in the 1990s and on recast phenomena more recently (e.g. Sheen 2008) have drawn attention to modifications performed to promote mutual understanding in interaction. Surprisingly enough, even in these studies the focus has mainly been on either native or non-native behaviour, not both at the same time.

These approaches are in many ways promising but still limited to if our goal is to understand the interplay between the social and formal sides of language learning. As a whole, the formal and social aspects of language learning have still basically been kept apart in both first and second language research: the language to be learnt has been isolated from interaction, and vice versa.

\section{Complexity and segmentation}

In traditional first language acquisition studies, the emphasis has been on form or structure: the key questions have been about how many linguistic structures a child uses and what they are like, and what linguistic schemata the child has acquired and in what order he/she has acquired them. A general assumption is that with such structural indicators children's language development can be assessed and also compared to that of others. Structural complexity has been considered an essential developmental indicator in the field of first language acquisition. The basic idea is that a child proceeds from simple elements to more and more complex structures (Smith and van Kleeck 1986) and development is manifested in expressive language which becomes structurally more complex (Nieminen 2007: 17). 
In contrast, the word complexity has rather seldom been used to refer to the structural properties of learner language within second language research. The main contexts in which the word has previously been used are with reference to task complexity within language pedagogy (e.g. Robinson and Gilabert 2007) and testing the applicability of chaos/complexity theory in second language learning (Larsen-Freeman 2002). More recently, however, structural complexity has started to gain more attention within this field, too. The challenge of defining and operationalizing structural complexity and relating it to fluency and accuracy is now under debate (Pallotti 2009, Larsen-Freeman 2009).

Martin's (1995) research, in which she explored the effect of structural complexity on learning second language nominal inflection, is among the earliest studies discussing these issues. The language to be learnt was Finnish, and the findings have influenced the ways in which Finnish is taught nowadays. The relevance of complexity, in addition to fluency and accuracy, is emphasized in current Finnish as a second language pedagogy (Nissilä et al. 2006). Furthermore, the formal approach in Finnish as a second language pedagogy has been criticized for being grounded on an assumed order of complexity (see Aalto 1997) which is hardly in accordance with the natural learning order. Based on standard language structures, the description of simple and "easy" constructions as opposed to complex and "difficult" structures is not necessarily a relevant starting point for deciding the teaching order of structural elements of a language.

The question of order has been taken seriously at least since the 1970s, when studies focusing on second language learning order were popular. The so-called Natural Order Hypothesis was influential in both first and second language studies (Lightbown and Spada 1999). Later on, phenomena related to order and complexity have been discussed in Pienemann's (1998 and 2005) studies. The aim of his studies is to investigate a learner's progress on a hierarchical continuum of structures: how large units are processable or learnable by the learner at a certain stage, and thus teachable as well. Crosslinguistic comparison has played an important role in development of the Processability Theory as well as in tracing universalities in language learning (see Pienemann 2005). The validity of this theory has already been partially tested - and challenged - for Finnish language by Martin (2004). 
The existence and use of various quantitative complexity measures shows the important role that complexity has gained in first language acquisition studies. The best known measure is Mean Length of Utterance (MLU; Brown 1973), which describes complexity on the basis of the average number of morphemes in child utterances. However, this kind of description flattens the structure of language into a linear row of morphemes (Nieminen 2007: 58). Statistical analysis is easy to apply to MLU values, but it does not give information about the language use in the utterances on which the average numbers are based. Another quantitative measure of complexity is the Index of Productive Syntax (IPSyn; Scarborough 1990, Nieminen and Torvelainen 2003). IPSyn focuses on forms and constructions and especially on manifestations of them in a child's speech. It identifies complexity as the diversity of morphosyntactic resources and not as the linear length of utterances, as in MLU.

Although both MLU and IPSyn are inadequate as measures of the multidimensional properties of structural complexity, they do help us to see the general outlines of development when used together. (Nieminen 2007 and 2009). In Nieminen's (2007) study these measures revealed how the growth of structural complexity developed in several directions in 30-month-old children's utterances. The children usually started with morphological elaboration in only one component in an utterance. However, according to IPSyn results the same children had a very versatile repertoire of constructions. Thus, constructional resources and length of productions reflect different aspects of structural complexity. The same contradiction between MLU and IPSyn results recurred when children moved on to the second phase of development and elaborated two elements in an utterance. This time the contradiction was created by homogenous IPSyn results and extremely varied MLU scores. This indicated that the combining of structural resources had begun and resulted in longer utterances. In the next phase, however, structural resources (that is, IPSyn score) grew again. The explanation is that the children were not just combining resources in an utterance, but were adding structural features within each element in the utterance and thus expanding the inventory of their resources.

In second language studies, MLU has been a fairly widely used but also a widely criticized method (see e.g. Perdue 1993: 134). Most of the criticism has focused on the fact that MLU con- 
centrates on linguistic structures alone, and therefore it cannot be used in the evaluation of language proficiency. Some researchers have also used Mean Length of Turn (MLT), a fairly rough measure based on words instead of morphemes, which indicates increase in fluency and in combining syntactic units (see e.g. Jiménez et al. 2006 and Richards and Malvern 2000). In studies concerning Finnish as a second language, MLU has not been used until now, but Suni (2008) has used MLT in describing how the amount of speech is divided between interlocutors in a conversation and how a native speaker adjusts his or her way of speaking to that of language learners. Also IPSyn is a very seldom used measure in second language studies. In a pilot study reported by Suni (2006), however, the Finnish version of IPSyn (Nieminen and Torvelainen 2003) proved to be a promising tool, at least in a longitudinal study concerning children learning Finnish as a second language.

Although complexity has had different roles in first and second language research and complexity measures have been used for different purposes, it is possible to see segmentation, that is, the chopping of linguistic material into units (see e.g. Peters 1985 and 1997), as a factor common to them all. What distinguishes one approach or paradigm from another, however, is that in some cases the one who actually makes the segmentation is the researcher, and in others it is the language user him- or herself.

Both MLU and IPSyn represent an absolute approach to complexity (Dahl 2004, Miestamo 2006 and Nieminen 2007: $56-57,2009)$ which only takes into account the structural complexity of the language and excludes the language user and his/ her experience of difficulty or ease with the language. In the absolute approach to complexity it is the researcher who does the segmentation of linguistic material. MLU and IPSyn measure iterative structural patterns in language: morphemes in MLU (or words in MLT) and structures previously defined as essential in the given language in IPSyn (Nieminen 2007: 56). This researcher-oriented procedure causes a major problem when it comes to the analysis. Although Brown (1973) requires that only productive morphemes are counted in MLU, and the emerging productivity of structures, in turn, is evaluated in IPSyn, the units used in analysis are not necessarily psychologically realistic units for the language user. What individuals produce is thus not 
necessarily based on the application of formal rules, at least not to the extent that these analyses imply.

In first language acquisition studies, erroneous morphological forms have traditionally been considered evidence of the segmentation process. Word forms like ulkonasta (pro ulkoa 'from outside'; the erroneous form has two inflectional suffixes ulko+ESSIVE+ELATIVE, which is not possible in Finnish), venejä (pro veneitä 'boat+PL+PARTITIVE'; use of the singular stem vene- instead of the required plural one venei- and consequently the wrong partitive suffix variant $-\ddot{a}$ instead of -tä) and käsit (pro kädet 'hands'; in the erroneous form the plural suffix is attached to the basic form $k a ̈ s i+\mathrm{PL}$ and not to the required stem käde+PL) suggest that a child has created his or her own rule about how particular inflectional elements are used and what meanings they convey. These errors have been seen as supporting the idea that in language learning it is basically a question of learning the rule system governing the language. At this "error stage" the child has perceived regularities in the language and is acting accordingly; they have not yet got to the stage of recognising that there are sometimes exceptions to the rules. (Plunkett and Marchman 1993: 22.) However, a language user's authentic units of processing are very difficult to recognise because erroneous inflection is an infrequent phenomenon. As such it gives only limited evidence of segmentation concerning inflectional system as a whole.

Rather different evidence of segmentation is offered by data consisting of dialogues, where the learners are involved in social interaction with other people and where their language is not analysed in isolation, as if they were producing monologues.

\section{Segmentation and interaction}

Ann Peters (1985) has noted that in first language development, a prerequisite for productive use of morphological elements is that the child first learns to segment them receptively. The child thus has to learn to recognise morphological elements in the speech of others before their own productive use of these elements can develop. This has not yet been investigated in the context of Finnish as L1, but the following excerpt (Example 1) shows that receptive segmenting plays a crucial role when the child (CHI) 
interacts with her mother (MOT) and a researcher (EXP). The conversation between the two and a half year old child and the adults takes place during play with farm animal toys.

(1)

MOT: oNk+se noittem ponier ruokaa? Is it those ponies' food?

EXP: $m m \#$

CHI: oni: \#\#

CHI: uиa oni:

EXP: $<m m>[>]$

$\mathrm{mm}$

pony

food pony

MOT: $<$ nii $>[<]$ tykkääk+se siitä?

$\mathrm{mm}$

CHI: $y k k \ddot{a} \ddot{a}$

MOT: joo

yes, does it like it?

(it) likes

[=! whispering $]$ yeah

The child first extracts the word oni: ('pony') from her mother's utterance. However, instead of repeating the same inflectional form as her mother used (ponien 'ponies' genitive case) she seems to segment the basic form of the word. Immediately after that the child uses a larger extraction (uиa oni: 'food pony'), a whole noun phrase, but again in basic form and also with changed word order. Neither of these extractions are pure repetitions; they also involve linguistic modification. The next utterance by the mother is a simple question tykkääk+se siitä? ('Does it like it?'), and the child answers by segmenting a suitable verb form from her mother's utterance: $y k k \ddot{a} a ̈$ ('(it) likes').

Similar processing takes place when children are learning a second language. In the example below, a 5-year-old child is segmenting verb forms when repeating parts of preceding adult utterances, which are in a question form and thus call for an answer.

EXP: käyttekste kaupassa?

CHI: käy

EXP: hm. mitäs sä sitte teet kotona \#

illalla sitte ku sä oot ollu

päiväkodissa?

nii mitä sä teet sen jälkeen?

\# \# laittaaks äiti teille ruokaa?

CHI: (l)aittaa do you go shopping?

go

$\mathrm{hm}$. what do you do at home?

in the evening when you have been at nursery? so what do you do after that? does mummy make dinner for you? (she) makes 
The child adequately answers questions with one-word utterances that include only a segmented form of the verb which the adult interlocutor has just introduced. Both segmentations lead to 3rd person singular forms, although a 2nd person plural form could be expected on the first occasion. Repeating the key verb of the preceding turn is an adequate way of responding to the questions asked. In general, for this particular child segmenting is a dominant strategy for participating in interaction at this particular stage of second language development. She relies very clearly on the preceding turn of her interlocutor, and by picking up and segmenting the key word she avoids the need to invent the word for herself.

Such receptive segmenting also appeared to be a central phenomenon in a longitudinal study reported by Suni (2008) which dealt with the role of repetition in conversations between a native speaker and two adult learners of Finnish early on in their language learning. Repetition was the most important means of negotiating meanings, and it was at the same time a forum for intensive linguistic recycling. The processing of linguistic forms was frequently involved in repetitions, and even morphological modifications were common, although they have not been found in prior studies on negotiations of meaning (see Pica 1994).

The learners of Finnish had an isolating language, Vietnamese, as their first language. This means that they had no prior experience of such morphological phenomena as inflection and derivation. When they continuously encountered the morphological features of Finnish in conversation they first started to segment morphological elements of native speaker utterances while repeating them (see Peters 1985). Such segmentation was shown to serve the goal of comprehension: the learners tried to grasp something familiar behind the inflections and derivations. In Example 3, the learner (NNS) segments the form rauhallista 'peaceful' into the form rauha 'peace' and thus segments both the derivative $(-l l i+s)$ and inflective (partitive case $-t a$ ) suffixes out. What remains after such a deletion process is the root of the derivative, rauha. After this, the native speaker gives minimal confirmatory feedback and only then brings the segmented parts back and offers another expression synonymous with the one originally used. 
(3)

NS: onko siellä rauhallista?

is it peaceful there?

NNS: rauha?

NS: $\quad m m$

peace?

$\mathrm{mm}$

NS: \# rauhallista \# hiljaista \# peaceful silent voiko siellä hyvin opiskella?

can one study well there?

In spite of performing such receptive segmenting, the Vietnamese learners of Finnish seemed to be immune to the morphological modification suggested to them. They incorporated lexical items and syntactic constructions, but morphology was a black hole. They did not incorporate any morphemes offered by their interlocutor in the form of modified other-repetitions, and what is also worth noticing is that neither did they add morphemes missing in their own prior turns when modifying them further in self-repetitions. This resistance is illustrated in Example 4, where inflection is overtly offered, but the learner is not ready to give up the basic form vanha paita 'old shirt' which he originally used when talking about the activities of his friend in the flea market.

NNS: hän myö\# paita

NS: vaatteita

NNS: \# vanha paita

NS: vanhoja paitoja?

NNS: joo vanha paita hää

hän kauppa \# nimi on öö \# www he sells \# shirt

clothes

old shirt

old shirts?

yeah old shirt

he shop name is erm

www [name].

In this example, the plural partitive form, twice offered by the interlocutor, does not get through and become incorporated. By segmenting the offered inflected form vanhoja paitoja receptively, the learner shows that he recognizes these words, however.

Such examples show that finding a basic form behind the inflection and sound-alternations connected to it may sometimes require a rather deep understanding of linguistic structures. Unfortunately the follow-up did not cover the productive phase of morphological processing, so this could not be observed. As with the first language, so also with the second language such 
development in a productive phase could partially be observed through morphophonological deviations from adult/nativelike language use. This calls for recognition of the psychologically relevant units of linguistic processing and the role of analogy. However, the context should be interactional, and preceding utterances should also be considered potential sources of any new formulations and combinations.

Segmentation is not something that "less capable" interlocutors do alone. Example 5 illustrates how segmentation (by NS) also acts as a NS means of increasing morphological saliency and promoting understanding.

$\begin{array}{lll}\text { NS: } & \text { käytkö sinä kirjastossa? } & \text { do you go to the library? } \\ \text { NNS: } & 0 & 0[=\text { no response }] \\ \text { NS: kirjasto \# }<\text { tie }>[>] & \text { library do you kn- } \\ \text { NNS: }<\text { joo }>[<] \# \text { kirja \# kirja } & \text { yeah book } \\ \text { NS: kirjasto } & \text { library } \\ \text { NNS: } \text { mene? } & \text { go? } \\ \text { NS: } m m & \mathrm{~mm}\end{array}$

The learner does not answer the question he is asked, which prompts a segmentation process. The NS segments the local case ending -ssa of the inflected form kirjastossa 'in the library', which she introduced in her previous turn without getting any response. She ends up with the basic form kirjasto 'library'. The NNS goes on to segment the derivative ending -sto, which refers to a collection of something (here: 'a collection of books'), which the NS immediately returns to its previous position. This leads to a shared understanding that it's a question of a location and not a book. This is signalled by the verb choice mene 'to go' by the NNS.

The excerpts discussed so far illustrate how language forms are processed in interaction in which one of the participants is an early stage second language learner. On the growth of complexity they hardly give any clear signs. Employing MLU or IPSYN would probably give more information on the (lack of) structural complexity of their language forms used, but it would at the same time exclude what a qualitative analysis reveals: the processing of linguistic forms is attached to repetitions, and sharing linguistic resources with a more competent interlocutor is an essential part 
of such processing. Such aspects are not identifiable in complexity measures, because imitated or repeated linguistic material is left out of such analyses. The remaining questions thus are, how to analyse complexity without reducing it as a phenomenon, and how to operationalize developing complexity so that the social aspects of processing are taken into account.

Another crucial observation concerns the recycling of linguistic elements. Other-repetition clearly outnumbers selfrepetition in the data from which some samples have been presented here and unmodified repetitions are extremely rare in comparison with modified repetitions (see Suni 2008). This means that both participants rely on each other's utterances, and linguistic resources are to a great extent shared by the participants. It is thus not only learners who lean on native speaker turns, but this can also happen the other way around.

Quite similar observations have been made in first language research. Both children and adults tend to re-use formulas that have already been introduced in earlier interaction. Altenberg (1990) has estimated that as much as $70 \%$ of adult speech is based on speech formulae and prefabricated models. In case studies concerning child language, $37 \%$ of multi-word expressions differed from expressions they had used earlier, and $74 \%$ of these only differed by one single feature such as an added or deleted word (Lieven et al. 2003). Such findings force us to reassess the role of productivity and the productive use of forms in language acquisition. Is segmentation necessary, and what are the segments actually like?

It is obvious that to understand the role of segmentation in relation to both interaction and the development of complexity, a new contextualization of the whole issue is needed. In the final section we will briefly discuss some viewpoints and concepts suggested by sociopragmatic, sociocultural and sociocognitive approaches to the phenomena observed above.

\section{Discussion}

A usage-based approach to first language acquistion, also referred to as a sociopragmatic view (see Tomasello 2000), emphasizes that language is first learnt and used as unanalyzed chunks, and perceiving language and its use is based on construc- 
tions (Tomasello 2003 and Lieven et al. 2003). Second language research already offers some support for such a view (Eskildsen 2008), and our own empirical findings are also in accord with it.

The usage-based model is based on Langacker's (e.g. 1988) view of cognitive grammar: the grammar simultaneously consists of concrete and abstract items, and all the elements of language are included in it. The grammar is a "structured inventory of conventional linguistic units" (Langacker 1988: 130, Leino 1989). Language users have access to units of both levels of abstraction. Language development thus involves a segmentation process, but the result is not a rule-based language use only.

Both frequency of occurrence and phonological saliency are present in interaction, and they are also related to segmentation of forms. Interaction between children and adults - and in the same way native-non-native interaction as well - should thus be analysed by focusing on the means it gives for linguistic segmentation and more complex use of language. Various repairs and modified repetitions (elaborated and segmented repetitions) are interactional means that strengthen both phonological and morphological saliency and also raise the frequency of occurrences. They support the segmentation process, and allow comparisons within an inflection paradigm when several forms of each item are present in close succession to each other. According to Painter (1999), a language learner is an active agent who manipulates language by repeating, repairing and modifying and so practises segmenting components of the language in a natural context. Language is thus both the target and the means of learning.

If the usage-based approach pays a lot of attention to individuals figuring out linguistic forms, the socio-cultural approach emphasizes the other participants in the interaction and their role. This approach has its roots in Vygotskian thinking, especially in Vygotsky's ideas on learning as a process in which support given by more capable adults or peers is crucial (see Vygotsky 1978); e.g. Lantolf and Thorne (2006) have applied such ideas in second language contexts. Among the key notions is scaffolding, which refers to tailored and timely interactional support offered to a learner who is struggling with some kind of problem-solving. When problems of understanding occur in conversation, modified repetitions serve as scaffolding by increasing saliency and offering a syntactic frame to be filled in (Suni 2008). Scaffold- 
ing is useful within Zones of Proximal Development (ZPD) only, which means that it has to be directed at processable but not yet independently managed phenomena. For example, a linguistic form which can not yet be processed in spite of the aid given by others is still too complex to get learnt.

The sociocultural approach does not offer means for analysing concrete linguistic items, but as a view of learning it gets support from our empirical observations. However, it requires a view of language which recognises that the origin and essence of language is social. The dialogical view of language, based on Bakhtin's (1981 and 1986) notions of language as "no-one's own" offers a relevant and more holistic view of language acquisition in relation to interaction, modification and complexity. One of the basic ideas of dialogism is that all that is said is a reaction to previous utterances, and at the same time this lays the basis for the interlocutors' further utterances. Language is thus recycled and adapted to new needs. Language and linguistic expressions are not seen as the property of individuals only; linguistic processing is inherently shared and is neither activity based nor driven only by individual cognition (Dufva 1998 and 2000, Linell 1998.) This is what differentiates the so-called sociocognitive approaches from other points of view (see Alanen 2000).

When learning a language, individuals rely on collective linguistic resources and on the spoken and written language saved in different forms in the environment. They appropriate language by acting with surrounding people and texts (van Lier 2000, Johnson 2003). Language and its learning are thus not separate from other aspects of human life, nor are they "only cognitive"; they are inherently social phenomena. (Dufva 1998, van Lier 2000). Segmentation can be seen as a part of an appropriation process related to social and linguistic action.

Even the "items" to be segmented are not necessarily purely linguistic in nature. Interaction involves various forms of speaking and writing (heteroglossia, as Bakhtin 1981 calls it; see also Dufva et al. 2011), which sets the question of segmentation in a larger framework. The structural complexity of language is intertwined with various social structures, and the learner is faced with highly variable linguistic features throughout the learning process.

The sociopragmatic, socio-cultural and socio-cognitive approach shed light on the connections between segmentation, complexity and interaction in their own different but relevant 
ways. An essential shared feature between them is that interaction is not seen as "interaction only". It is the breeding ground of forms, facilitating the development of noticing, segmentation and language itself. What remains a challenge for the future is to combine the strengths of each approach at the level of empirical work in both first and second language interaction data.

\section{Acknowledgements}

The article has been written in the research project Dialogues of appropriation: Dialogical approaches to language learning and teaching funded by the Academy of Finland and directed by Prof. Hannele Dufva (see also Nieminen and Suni 2009 (in Finnish).

Addresses:

Minna Suni

Department of Languages

P.O.Box 35

40014 University of Jyväskylä

Finland

E-mail: minna.suni@jyu.fi

Lea Nieminen

Centre for Applied Language Studies

P.O.Box 35

40014 University of Jyväskylä

Finland

E-mail:lea.s.m.nieminen@jyu.fi

\section{References}

Aalto, Eija (1997) “Oppimateriaalien muuttuvat oppimiskäsitykset”. In AnnaMaija Raanamo and Paula Tuomikoski, eds. Kielisillan rakentajat: katsaus ulkomaanlehtori- ja kielikurssitoimintaan ja toiminnan arviointi, 46-51. Helsinki: Edita.

Alanen, Riikka (2000) "Vygotsky, van Lier ja kielenoppiminen: sosiokulttuurinen viitekehys kielellisen tietoisuuden ja vieraan kielen oppimisen 
tutkimuksessa". In Paula Kalaja and Lea Nieminen, eds. Kielikoulussa - kieli koulussa, 95-120. (AFinLAn vuosikirja 2000.) Suomen soveltavan kielitieteen yhdistyksen julkaisuja nro. 58. Jyväskylä: AFinLA.

Altenberg, Bengt (1990) "Speech as linear composition". In Graham Caie, Kirsten Haastrup, Arnt Lykke Jakobsen, Jorgen Erik Nielsen, Jorgen Sevaldsen, Henrik Specht, and Arne Zettersten, eds. Proceedings from the Fourth Nordic Conference for English Studies. Vol. 1, 133-143. Copenhagen: Department of English, University of Copenhagen.

Bakhtin, Mihail M. (1981) The dialogic imagination: four essays. Transl. Caryl Emerson and Michael Holquist, ed. Michael Holquist. Austin, Texas: Texas University Press.

Bakhtin, Mihail M. (1986) Speech genres and other late essays. Transl. Vern W. McGee, eds. Caryl Emerson and Michael Holquist. Austin, Texas: Texas University Press.

Brown, Roger (1973) A first language. The early stages. Harmondsworth: Penguin Education.

Dahl, Östen (2004) The growth and maintenance of linguistic complexity. Amsterdam: John Benjamins.

Dufva, Hannele (1998) "From 'psycholinguistics' to a dialogical psychology of language: Aspects of the inner discourse(s)". In Mika Lähteenmäki and Hannele Dufva, eds. Dialogues on Bakhtin: interdisciplinary readings, 87-105. Jyväskylä: Centre for Applied Language Studies.

Dufva, Hannele (2000) "Kirjoitettu kieli, kognitio ja emergenssi”. In Urho Määttä, Tommi Nieminen, and Pekka Pälli, eds. Emergenssin kielelliset kasvot, 155-182. (Folia Fennistica and Linguistica, 24.) Tampere: Tampereen yliopiston suomen kielen ja yleisen kielitieteen laitos.

Dufva, Hannele, Minna Suni, Mari Aro, and Olli-Pekka Salo (2011) "Languages as objects of learning: language learning as a case of multilingualism". Apples - Journal of Applied Language Studies 5, 1, 109-124.

Ervin-Tripp, Susan M. (1974) "Is second language learning like the first?" TESOL Quarterly 8, 124.

Eskildsen, Søren W. (2008) "Constructing another language”. Applied Linguistics 30, 3, 335-357.

Ferguson, Charles A. (1975) "Toward a characterization of English foreigner talk". Anthropological Linguistics 17, 1-14.

Gass, Susan M. (1997) Input, interaction, and the second language learner. Mahwah, NJ: Lawrence Erlbaum Associates.

Jiménez, Terese C., Alexis L. Filippini, and Michael M. Gerber (2006) "Shared reading within Latino families: an analysis of reading interactions and language use". Bilingual Research Journal 30, 2, 431-452.

Johnson, Marysia (2003) A philosophy of second language acquisition. London: Yale University Press. 
Karlsson, Fred (1983) Suomen kielen äänne- ja muotorakenne. Porvoo: WSOY.

Karlsson, Fred (1998) Yleinen kielitiede. Helsinki: Helsinki University Press.

Krashen, Stephen D. (1982) Principles and practice in second language acquisition. Oxford: Pergamon.

Keenan, Elinor (1974) "Making it last: repetition in childrens's discourse". In Susan Ervin-Tripp and Claudia Mitchell-Kernan, eds. Child discourse, 125-138. New York: Academic Press.

Kurhila, Salla (2006) Second language interaction. Amsterdam: John Benjamins.

Laakso, Minna (2008) "Lasten vuorovaikutusaineistojen keskusteluanalyyttinen tutkimus: metodipohdintoja”. Puhe ja kieli 28, 149-166.

Langacker, Roland (1988) “A usage-based model”. In Brygida Rudzka-Ostyn, ed. Topics in cognitive linguistics, 127-161. (Current Issues in Linguistic Theory, 50.) Amsterdam: John Benjamins.

Lantolf, James P. and Steven L. Thorne (2006) Sociocultural theory and the genesis of second language development. Oxford: Oxford University Press.

Larsen-Freeman, Diane (2002) "Language acquisition and language use from a chaos/complexity theory perspective". In Claire Kramsch, ed. Language acquistion and language socialization: ecological perspectives, 33-46. London: Continuum.

Larsen-Freeman, Diane (2009) "Adjusting expectations: the study of complexity, accuracy, and fluency in second language acquisition”. Applied Linguistics 30, 4, 579-589.

Leino, Pentti (1989) "Paikallissijat ja suhdesääntö: kognitiivisen kieliopin näkökulma”. Virittäjä 93, 161-219.

Lieven, Elena, Heike Behrens, Jennifer Speares, and Michael Tomasello (2003) "Early syntactic creativity: a usage-based approach". Journal of Child Language 30, 333-370.

Lightbown, Patsy M. and Nina Spada (1999) How languages are learned. Oxford: Oxford University Press.

Lilja, Niina (2010) Ongelmista oppimiseen. Toisen aloittamat korjausjaksot kakkoskielisessä keskustelussa. (Jyväskylä Studies in Humanities, 146.) Jyväskylä: University of Jyväskylä.

Linell, Per (1998) Approaching dialogue: talk, interaction and contexts in dialogical pespectives. Amsterdam: John Benjamins.

Long, Michael H. (1983) "Native speaker/non-native speaker conversation and the negotiation of comprehensible input". Applied Linguistics 4, 2, 126-141.

Long, Michael H. (1985) "Input and second language acquisition theory". In Susan Gass and C. Madden, eds. Input in second language acquisition, 377-393. Rowley, MA: Newbury House. 
Long, Michael H. (1996) "The role of the linguistic environment in second language acquisition". In William C. Richie and Tej K. Bhatia, eds. Handbook of second language acquisition, 413-468. San Diego: Academic Press.

Martin, Maisa (1995) The map and the rope: Finnish nominal inflection as a learning target. (Studia Philologica Jyväskyläensia, 38.) Jyväskylä: University of Jyväskylä.

Martin, Maisa (2004) "Three structures of Finnish and the processability theory". In Lena Ekberg and Gisela Håkansson, eds. NORDAND 6. Sjätte konferensen om Nordens språk som andraspråk, 201-212. Lund: Lunds universitet, Institutionen för nordiska språk.

Miestamo, Matti (2006) "On the feasibility of complexity metrics". In Krista Kerge and Maria-Maren Sepper, eds. FinEst linguistics. Proceedings of the annual Finnish and Estonian conference of linguistics. Tallinn, May 6-7, 2004, 11-26. (Tallinna Ülikooli eesti filoloogia osakonna toimetised, 8.) Tallinn: Tallinn University Press.

Nieminen, Lea (2007) A complex case: a morphosyntactic approach to complexity in early child language. (Jyväskylä Studies in Humanities, 72.) Jyväskylä: University of Jyväskylä.

Nieminen, Lea (2009) "MLU and IPSyn measuring absolute complexity". Eesti rakenduslingvistika ühingu aastaraamat. Estonian Papers in Applied Linguistics 5, 173-185.

Nieminen, Lea and Minna Suni (2009) "Vuorovaikutus kompleksisuuden kasvualustana ensikielessä ja toisessa kielessä”. In Jyrki Kalliokoski, Tuija Nikko, Saija Pyhäniemi, and Susanna Shore, eds. Puheen ja kirjoituksen moninaisuus. Variationsrikedom i tal och skrift. The diversity of speech and writing, 119-138. (AFinLA Yearbook, 67.) Jyväskylä: AFinLA.

Nieminen, Lea and Päivi Torvelainen (2003) "Produktiivisen syntaksin indeksi - suomenkielinen versio". Puhe ja kieli 23, 119-132.

Nissilä, Leena, Maisa Martin, Heidi Vaarala, and Ilona Kuukka (2006) Saako olla suomea? Opas suomi toisena kielenä -opetukseen. Helsinki: National Board of Education.

Painter, Clare (1999) Learning through language in early childhood. London: Continuum

Pallotti, Gabriele (2009) "CAF: defining, refining and differentiating constructs". Applied Linguistics 30, 4, 590-601.

Perdue, Clive, ed. (1993) Adult language acquisition. Cross-linguistic perspectives. Vol. 1: Field methods. Cambridge: Cambridge University Press.

Peters, Ann (1985) "Language segmentation: Operating principles for the analysis and perception of language". In Dan I. Slobin, ed. The crosslinguistic study of language acquisition. Vol. 2. Theoretical issues, 1029-1067. Hillsdale, NJ: Lawrence Erlbaum Associates. 
Peters, Ann (1997) "Language typology, prosody, and the acquisition of grammatical morphemes". In Dan I. Slobin, ed. The crosslinguistic study of language acquisition. Vol. 5. Expanding the context, 135-197. Mahwah, NJ: Lawrence Erlbaum Associates.

Pica, Teresa (1994) "Research on negotiation: what does it reveal about secondlanguage learning conditions, processes and outcomes?". Language Learning 44, 493-527.

Pienemann, Manfred (1998) Language processing and second language development: processability theory. Amsterdam: John Benjamins.

Pienemann, Manfred, ed. (2005). Cross-linguistic aspects of processability theory. Philadelphia: John Benjamins.

Plunkett, Kim and Virginia Marchman (1993) "From rote learning to system building: acquiring verb morphology in children and connectionist nets". Cognition 48, 21-69.

Richards, Brian J. and David D. Malvern (2000) "Accomodation in oral interviews between foreign language learners and teachers who are not native speakers". Studia Linguistica 54, 2, 260-271.

Robinson, Peter and Roger Gilabert (2007) "Task complexity, the cognition hypothesis and second language learning and performance". International Review of Applied Linguistics in Language Teaching (IRAL) 45, 3, 161-176.

Scarborough, Hollis S. (1990) "Index of productive syntax". Applied Psycholinguistics 11, 1-22.

Scarborough, Hollis S. (1991) "Early syntactic development of dyslectic children". Annals of Dyslexia 41, 207-220.

Smith, Carlota S. and Anne van Kleeck (1986) "Linguistic complexity and performance". Journal of Child Language 13, 389-408.

Sheen, Younghee (2008) "Recasts, language anxiety, modified output, and L2 learning. Language Learning 58, 4, 835-874.

Snow, Catherine E. (1979) “Conversations with children”. In Paul Fletcher and M. Garman, eds. Language acquisition, 363-375. Cambridge: Cambridge University Press.

Suni, Minna (2006) "Lasten toisen kielen kehitys IPSyn-kokeilun valossa". In Hannu Tommola and Anneli Pajunen, eds. XXXII Kielitieteen päivät Tampereella 19.-20.5.2005. Valikoima pidettyihin esitelmiin pohjautuvista artikkeleista, 427-439. Tampere: University of Tampere.

Suni, Minna (2008) Toista kieltä vuorovaikutuksessa. Kielellisten resurssien jakaminen toisen kielen omaksumisen alkuvaiheessa. (Jyväskylä Studies in Humanities, 94.) Jyväskylä: University of Jyväskylä.

Tomasello, Michael (2000) "The social-pragmatic theory of word learning". Pragmatics 10, 401-414. 
Tomasello, Michael (2003) Constructing a language. A usage-based theory of language acquisition. Cambridge, Massachusetts: Harvard University Press.

Van Lier, Leo (2000) "From input to affordance: social-interactive learning from an ecological perspective". In James P. Lantolf, ed. Sociocultural theory and second language learning, 245-260. Oxford: Oxford University Press.

Vygotsky, Lev S. (1978) Mind in society: the development of higher psychological processes. Michael Cole, Vera John-Steiner, Sylvia Scribner, and Ellen Souberman, eds. Cambridge, MA: Harvard University Press.

Kokkuvõte. Minna Suni and Lea Nieminen: Komplekssus ja interaktsioon: esimese keele ja teise keele arengu võrdlus. Esimese ja teise keele arengu alastes uurimustes on põhiliselt keskendutud kas ainult õppijakeele (nii esimese kui ka teise keele) formaalsetele omadustele, õppijate ja nende hooldajate (esimene keel) või õppijate ning nende emakeelt rääkivate kaaslaste (teine keel) suhtlusele. Neid uurimistavasid on hoitud lahus, kuigi üldiselt on teada, et nii esimene kui ka teine keel omandatakse eelkõige sotsiaalse suhtlemise kaudu. Käesoleva artikli eesmärk on tugevdada sidet sotsiaalse ja formaalse lähenemise vahel, ühendades suhtlusega seotud vaatepunktid seisukohtadega, mis keskenduvad õppijakeele struktuursele keerukusele. Artiklis võetakse vaatluse alla ka mõned keelenäited esimese ja teise keele vastastikuse mõju kohta (soome keeles). Väidetakse, et igapäevaelus toimub keelematerjali segmenteerimine ning see toimib ühenduslülina suhtlemise ja õppijakeele struktuurse keerukuse suurenemise vahel. Väite asetamiseks laiemasse teoreetilisse konteksti antakse lühiülevaade erinevatest sotsiaalsusest lähtuvatest uurimisparadigmadest.

Võtmesõnad: esimene keel, teine keel, suhtlemine, struktuurne keerukus, segmenteerimine, soome keel 